\title{
Tradisi lisan sebagai bahan pengembangan materi ajar Pendidikan IPS di SMP: sebuah telaah literatur
}

\author{
Een Syaputra * \\ Institut Agama Islam Negeri Bengkulu \\ eensyaputra23@gmail.com \\ Desy Eka Citra Dewi \\ Institut Agama Islam Negeri Bengkulu
}

\begin{abstract}
In addition to models, methods, and media, another aspect that is also very important in social studies is teaching material. As an essential element in the learning process, teaching materials must have adequate quality. Accordingly, this article is intended to offer a literature overview of oral traditions as material development for social studies in junior high schools, as well as to design conceptual models related to their application. This article is a conceptual article compiled based on the results of literature studies (books, journals, etc.) and document analysis (Core Competencies, Basic Competencies, Syllabus, etc.). There are three findings offered by this article. First, oral tradition is a potential source to be developed into social studies in junior high schools as it contains values of local wisdom and moral teachings which are relevant to the vision of social studies, namely as civic education. Also, oral traditions, which are part of anthropology and history, share the same nature to social study materialscombination of social science disciplines. Second, from several oral tradition variants, the most potent type to be inserted in social study materials are traditional expressions, folk poetry, folklore, and folk songs-by considering three things, namely: a) curriculum relevance; $b$ ) richness in value content; c) school environment-related issues. Third, three stages can be done in developing oral traditions as teaching materials, namely: a) analysis stage (identification of oral tradition and its relevance to curriculum); $b$ ) design and development stage (determining the form and structure of teaching materials required); and c) implementation stage.
\end{abstract}

Keywords: Oral Tradition; Teaching Material; Social Studies; Junior High School

\begin{abstract}
Abstrak
Model, metode, dan media merupakan aspek esensial dalam terlaksananya pembelajaran. Selain itu dalam Ilmu Pengetahuan Sosial adalah materi ajar menjadi fasilitator untuk mempermudah pencapaian tujuan pembelajaran. Sebagai elemen penting dalam proses pembelajaran, materi ajar harus memiliki kualitas yang memadai. Oleh karena itu, artikel ini dimaksudkan untuk menawarkan tinjauan literatur tentang tradisi lisan sebagai bahan pengembangan untuk studi sosial di sekolah menengah pertama, serta untuk merancang model konseptual yang terkait dengan aplikasi mereka. Artikel ini adalah artikel konseptual yang
\end{abstract}

* Korespondensi penulis 
disusun berdasarkan hasil studi literatur (buku, jurnal, dll) dan analisis dokumen (Kompetensi Inti, Kompetensi Dasar, Silabus, dll.). Secara garis besar, ada tiga temuan yang ditawarkan oleh artikel ini. Pertama, tradisi lisan merupakan sumber potensial untuk dikembangkan menjadi studi sosial di sekolah menengah pertama karena mengandung nilai-nilai kearifan lokal dan ajaran moral yang relevan dengan visi studi sosial, yaitu sebagai pendidikan kewarganegaraan. Selain itu, tradisi lisan, yang merupakan bagian dari antropologi dan sejarah, memiliki sifat yang sama dengan materi studi sosial-kombinasi dari disiplin ilmu sosial. Kedua, dari beberapa varian tradisi lisan, jenis yang paling potensial untuk dimasukkan ke dalam bahan studi sosial adalah ekspresi tradisional, puisi rakyat, cerita rakyat dan lagu-lagu rakyat-dengan mempertimbangkan tiga hal, yaitu: a) relevansi kurikulum; b) kekayaan konten nilai; c) masalah terkait lingkungan sekolah. Ketiga, ada tiga tahap yang dapat dilakukan dalam mengembangkan tradisi lisan sebagai materi ajar, yaitu: a) tahap analisis (identifikasi tradisi lisan dan relevansinya dengan kurikulum); b) tahap desain dan pengembangan (menentukan bentuk dan struktur materi ajar yang dibutuhkan); dan c) tahap implementasi.

Kata Kunci: Tradisi Lisan; Materi ajar; Ilmu Pengetahuan Sosial; Sekolah Menengah Pertama

Diterima 23 September 2019, Dipublikasikan 30 April 2020

\section{PENDAHULUAN}

Pentingnya pendidikan moral merupakan salah satu wacana dan gerakan yang masif dilakukan di Indonesia dalam beberapa tahun belakangan. Pemerintah Indonesia melalui Kementerian Pendidikan dan Kebudayaan mengeluarkan kebijakan bahwa pendidikan karakter merupakan program wajib untuk setiap mata pelajaran di semua jenjang pendidikan, mulai dari pendidikan dasar hingga pendidikan tinggi (Kemdikbud, 2010). Tidak hanya pemerintah, gerakan tentang pentingnya pendidikan karakter juga banyak dimotori oleh orang perorangan, komunitas, dan lembaga. Hal ini dilatarbelakangi oleh semakin maraknya perilaku amoral di tengah masyarakat dan institusi-institusi resmi pemerintahan. Sebut saja misalnya korupsi, pembunuhan, perampokan, sikap intoleransi, terorisme, dan lain sebagainya.

Pendidikan IPS merupakan mata pelajaran yang orientasi utamanya adalah pendidikan moral, terutama moralitas dalam konteks kehidupan bermasyarakat, berbangsa dan bernegara (Bank, 1990). Melalui pendidikan IPS, peserta didik dibekali dengan seperangkat kompetensi, baik pengetahuan, keterampilan ataupun sikap dan nilai-nilai agar dapat menjadi warga negara yang baik (NCSS, 1992; Winataputra, 2007). Untuk kompetensi pengetahuan, peserta didik dituntut untuk dapat memahami sejumlah fakta, konsep, generalisasi dan teori dalam ilmu-ilmu sosial dan humaniora yang dikemas dalam berbagai tema seperti sistem budaya, manusia, tempat dan lingkungan, konsumsi, produksi dan distribusi, waktu, keberlanjutan dan perubahan, sistem berbangsa dan bernegara, ilmu pengetahuan, teknologi dan masyarakat dan lain sebagainya (NCSS, 1992; Kemdikbud, 2018). Untuk kompetensi keterampilan, pembelajaran IPS mengembangkan setidaknya empat keterampilan, yakni: 1) keterampilan 


\section{Tradisi Lisan sebagai Bahan Pengembangan Materi ajar Pendidikan IPS di SMP: Sebuah Telaah Literatur}

meneliti; 2) keterampilan berpikir kritis, analisis dan kreatif; 3) keterampilan partisipasi sosial; dan 4) keterampilan berkomunikasi (Sapriya, 2009). Adapun untuk kompetensi sikap dan nilainilai, orientasinya lebih kepada emosi, perasaan dan kepercayaan tentang benar dan salah dalam konteks sebagai warga negara yang demokratis (Satria, 2016). Nilai-nilai tersebut antara lain seperti tanggung jawab, persaudaraan, loyalitas kepada negara dan lain sebagainya.

Lebih lanjut, Sapriya (2009:201) mengidentifikasi empat tujuan pendidikan IPS sebagai berikut: 1) mengenalkan konsep-konsep yang berkaitan dengan kehidupan bermasyarakat dan lingkungannya; 2) memiliki kemampuan dasar untuk berpikir logis dan kritis, rasa ingin tahu, inkuiri, memecahkan masalah dan keterampilan dalam kehidupan sosial; 3) memiliki komitmen dan kesadaran terhadap nilai-nilai sosial; 4) memiliki kemampuan berkomunikasi, bekerja sama dan berkompetisi di tingkat lokal, nasional dan global.

Dengan serangkaian kompetensi tersebut, maka pendidikan IPS diharapkan dapat memberikan kontribusi bagi terwujudnya peserta didik yang mampu mengambil keputusan dan melahirkan tindakan-tindakan yang rasional dalam menghadapi berbagai persoalan yang ada di masyarakat, terutama persoalan yang berhubungan langsung dengan kepentingan masyarakat luas. Lebih daripada itu, peserta didik bahkan diharapkan dapat menjadi aktor dan sekaligus agen bagi penyelesaian berbagai permasalahan yang ada.

Namun kenyataan di lapangan menunjukkan hasil yang sebaliknya. Pembelajaran IPS telah gagal dalam menumbuhkan nilai-nilai kemanusian kepada peserta didik. Pembelajaran IPS juga gagal dalam menumbuhkan keterampilan sosial dan kompetensi lain yang dibutuhkan untuk mewujudkan kehidupan sosial yang harmoni (Saripudin \& Komalasari, 2016). Tidak hanya itu, pembelajaran IPS juga gagal dalam mewujudkan peserta didik yang memiliki kemampuan pemecahan masalah. Dengan begitu, maka pembelajaran IPS di sekolah belum memberikan kontribusi yang memadai bagi terwujudnya warganegara yang baik sebagaimana visi utama pendidikan IPS.

Menghadapi persoalan tersebut, maka diperlukan evaluasi secara menyeluruh terhadap komponen-komponen pembelajaran IPS di sekolah. Salah satu elemen kunci yang mendapat sorotan ialah materi pembelajaran. Hasan (2012) mengungkapkan bahwa materi pembelajaran yang diajarkan di sekolah cenderung menjadi materi tentang fakta-fakta namun kering akan nilai-nilai. Karena itu, materi pembelajaran haruslah berubah menjadi materi yang kaya akan muatan nilai serta dapat menjelaskan kenyataan kehidupan masa kini. Hal ini sejalan dengan pendapat Supriatna (2011) yang mengatakan bahwa pembelajaran IPS menjadi kurang bermakna karena materi pembelajaran terlepas dari konteks sosial peserta didik. Lebih lanjut Birsyada (2016) menjelaskan bahwa muatan materi IPS di sekolah sama sekali tidak mencerminkan kondisi sosial budaya sehingga tidak mampu menghubungkan antara dunia pengetahuan dengan dunia realitas.

Dengan demikian, maka para guru IPS di sekolah dituntut untuk dapat mengembangkan materi pembelajaran yang kaya akan muatan nilai serta memiliki hubungan dengan permasalahan kekinian yang ada di lingkungan siswa. Untuk konteks Indonesia yang kaya akan 
aneka ragam kebudayaan lokal, salah satu alternatif yang dapat dilakukan ialah dengan memanfaatkan berbagai tradisi lisan yang ada masing-masing daerah. Sibarani (2013) berpendapat bahwa tradisi lisan mengandung nilai budaya yang dapat dimanfaatkan sebagai sumber pendidikan. Nilai budaya yang terkandung dalam genre tradisi lisan merupakan pesanpesan sebagai sumber pengetahuan atau pendidikan bagi generasi penerus. Lebih lanjut lagi Ratna (2014) berpendapat bahwa keseluruhan karya sastra, termasuk tradisi lisan pada dasarnya adalah pesan atau narasi yang berisi contoh dan teladan, hikmat dan nasehat, ganjaran yang berkaitan dengan pembentukan karakter.

Berdasarkan uraian di atas, maka dapat disimpulkan bahwa tradisi lisan merupakan salah satu sumber yang sangat potensial untuk digunakan sebagai bahan pengembangan materi ajar pendidikan IPS di SMP. Dengan memanfaatkan tradisi lisan yang kaya akan muatan nilai sebagai materi ajar, maka pembelajaran IPS akan menjadi lebih bermakna. Tidak hanya itu, mengembangkan materi ajar pendidikan IPS berbasis tradisi lisan juga dapat dipandang sebagai bagian dari usaha revitalisasi kebudayaan lokal sebagai identitas dan warisan budaya bangsa (Sariyatun, 2013; Syaputra, 2019). Karena itu, artikel ini akan melakukan telaah literatur tentang tradisi lisan sebagai bahan pengembangan materi ajar pendidikan IPS. Adapun pertanyaan pokok yang ingin dijawab adalah apa itu tradisi lisan? Apa saja kriteria tradisi lisan yang baik untuk materi ajar IPS? Bagaimana desain model konseptual tradisi lisan sebagai materi ajar IPS?

\section{METODE}

Penelitian ini merupakan penelitian kepustakaan dengan pendekatan deskriptif analisis, yakni serangkaian kegiatan yang berkenaan dengan metode pengumpulan data pustaka, membaca serta mencatat dan mengolah data penelitian (Zed, 2008:3). Karena itu, dalam penelitian ini, peneliti hanya membatasi diri bahan-bahan koleksi perpustakaan saja (buku, artikel jurnal, majalah ilmiah, media massa, laporan penelitian, dokumen kurikulum, dll), tanpa melakukan penelitian lapangan (observasi, wawancara dan lain-lain). Beberapa langkah yang dilakukan dalam penelitian ini adalah: 1) menyiapkan alat dan perlengkapan; 2) menyusun bibliografi kerja; 3) mengatur waktu penelitian; 4) membaca dan membuat catatan penelitian; dan 5) menyimpulkan dan menganalisis hasil penelitian (Zed, 2008).

\section{HASIL DAN PEMBAHASAN \\ Tradisi Lisan}

Tradisi lisan, sebagaimana dijelaskan oleh Duija (2005) merupakan segala wacana yang disampaikan secara lisan, mengikuti cara atau adat istiadat yang telah memola dalam suatu masyarakat. Sejalan dengan definisi di atas, Pudentia (2015) menerangkan bahwa tradisi lisan merupakan segala hal yang berhubungan dengan sastra, bahasa, sejarah, biografi, dan berbagai pengetahuan lain yang disampaikan dari mulut ke mulut. Adapun Sibrani (2015) mendefinisikan tradisi lisan sebagai kegiatan budaya tradisional suatu komunitas yang 


\section{Tradisi Lisan sebagai Bahan Pengembangan Materi ajar Pendidikan IPS di SMP: Sebuah Telaah Literatur}

diwariskan secara turun temurun dengan media lisan dari satu generasi satu ke generasi lain baik tradisi itu berupa susunan kata-kata ataupun tradisi lain yang bukan lisan.

Berdasarkan uraian di atas, dapat dipahami bahwa tradisi lisan tidak hanya tentang cerita rakyat, ungkapan tradisional, legenda dan lain-lain tetapi juga mencakup sistem kognitif kebudayaan seperti sejarah, hukum dan lain-lain. Definisi tradisi lisan juga dapat dijumpai dari karya James Danandjaja (2007) di mana tradisi lisan disamakan dengan foklor lisan, yakni memiliki bentuk murni lisan. Lebih lanjut dijelaskan bahwa yang masuk dalam kategori ini adalah, pertama, bahasa rakyat seperti logat, julukan, pangkat tradisional, dan titel kebangsawanan. Sebagaimana dijelaskan oleh Danandjaja (2007) bahwa bentuk-bentuk tradisi lisan yang masuk dalam kategori bahasa rakyat ini cukup banyak. Bentuk-bentuk tersebut antara lain logat atau dialek, slang atau bahasa rahasia, sirkumlokusi atau bahasa tidak langsung, pemberian nama dan julukan kepada seseorang, gelar kebangsawanan atau jabatan tradisional seperti mas, raden, raden mas, raden panji, raden tumenggung, dll, bahasa bertingkat, kata-kata onomatopoetic, dan lain-lain.

Kedua, ungkapan tradisional seperti peribahasa, pepatah, dan pemeo. Menurut Carvantes sebagaimana dikutip oleh Danandajadja (2007:28) ungkapan tradisional adalah kalimat pendek yang disajikan dari pengalaman yang panjang. Adapun Haryanto (2013:270) mendefinisikan ungkapan tradisional sebagai kata atau kelompok kata yang memiliki makna kiasan, konotatif, simbolis yang berasal dari tradisi atau kebiasaan turun-temurun masyarakat lokal dan diyakini mempunyai fungsi. Lebih lanjut dijelaskan bahwa ungkapan-ungkapan tersebut disarikan dari pengalaman panjang masyarakat yang dimunculkan dari kecerdasan lokal menjadi kebijaksanaan bersama masyarakat. Lebih lanjut dijelaskan oleh Danandjaja (2007) bahwa ungkapan tradisional memiliki tiga sifat hakiki, yakni: 1) berupa satu kalimat ungkapan; 2) ada dalam bentuk yang sudah standar; dan 3) mempunyai vitalitas atau daya hidup.

Ketiga, pertanyaan tradisional seperti teka-teki, pertanyaan tradisional di Indonesia lebih dikenal dengan nama teka teki, yakni pertanyaan yang bersifat tradisional dan mempunyai jawaban yang tradisional pula, (Danandjaja, 2007:33). Lebih lanjut dijelaskan bahwa teka teki dapat dibedakan menjadi dua jenis, yakni teka teki yang tidak bertentangan dan teka teki yang bertentangan.

Keempat, puisi rakyat seperti pantun, gurindam dan syair, sajak atau puisi rakyat adalah kesusastraan rakyat yang sudah tertentu bentuknya, biasanya terdiri dari beberapa deret kalimat, ada yang berdasarkan mantra, ada yang berdasarkan panjang pendeknya suku kata, lemah tekanan irama, atau hanya berdasarkan irama. Puisi rakyat dapat berbentuk macammacam, seperti ungkapan tradisional, pertanyaan tradisional, cerita rakyat, dan kepercayaan rakyat yang berupa mantra-mantra, (Danandjaja, 2007). Lebih lanjut dijelaskan bahwa satu kekhususan dari tradisi lisan jenis ini adalah bahwa kalimatnya tidak berbentuk bebas, melainkan berbentuk terikat. 
Kelima, cerita prosa rakyat seperti mitos, legenda dan dongeng, Cerita prosa rakyat merupakan jenis tradisi lisan yang paling banyak ditemukan. Menurut Bascom cerita prosa rakyat dapat dikelompokkan menjadi tiga jenis, yakni mitos, legenda dan dongeng. Pertama, mitos, yakni sebuah cerita prosa rakyat yang dianggap benar-benar terjadi dan dianggap suci oleh empunya cerita, (Danandjaja, 2007). Mitos ditokohkan oleh para dewa atau makhluk setengah dewa dan dengan latar dunia yang tidak seperti kita kenal sekarang. Kedua, legenda, yakni sebuah cerita prosa rakyat yang mirip dengan mitos, dianggap benar-benar terjadi namun tidak dianggap suci oleh empunya cerita. Selain itu, cerita dalam legenda juga di tokohi oleh manusia, meskipun kadang kala juga sering dibantu oleh para dewa. Ketiga, dongeng, yakni jenis cerita prosa rakyat yang dianggap tidak benar-benar terjadi oleh empunya cerita serta tidak pula terikat tempat dan waktu, (Danandjaja, 2007:50). Contoh dari cerita prosa rakyat jenis dongeng ini adalah seperti dongeng Si kancil dan Harimau, Si Beruk dengan Besan, dan lain-lain.

Dan terakhir, keenam, nyanyian rakyat, Menurut Brunvand, nyanyian rakyat adalah salah satu bentuk atau genre foklor yang terdiri dari kata-kata dan lagu, yang beredar secara lisan diantara anggota kolektif tertentu, berbentuk tradisional serta banyak mempunyai varian, (Danandjaja, 2007:141). Lebih lanjut dijelaskan bahwa nyanyian rakyat mempunyai beberapa ciri khusus yang membedakannya dengan genre folklor lainnya dan juga nyanyian pada umumnya, yakni seperti: 1) berasal dari berbagai macam sumber dan muncul dari bermacammacam media; 2) dalam nyanyian rakyat kata-kata dan lagu merupakan dwitunggal yang tak terpisahkan; 3) mudah berubah-ubah baik bentuk ataupun isinya; 4) peredarannya lebih luas dan berumur lebih tua dibandingkan lagu-lagu lainnya; 5) diwariskan secara lisan sehingga dapat menimbulkan varian-varian.

Sama seperti jenis tradisi lisan lainnya, nyanyian rakyat juga terbagi atas jenis-jenis. Dananjdaja (2007) membagi nyanyian rakyat ke dalam tiga kategori besar, yakni: 1) nyanyian rakyat yang berfungsi, yakni nyanyian rakyat yang lagu dan kata-katanya memegang peran sama penting. Nyanyian jenis ini kemudian terbagi lagi menjadi tiga, yakni nyanyian kelonan, nyanyian kerja, dan nyanyian permainan; 2) nyanyian rakyat yang bersifat liris, yakni nyanyian rakyat yang teksnya bersifat liris, yang merupakan pencetusan rasa haru pengarangnya yang anonim, tanpa menceritakan kisah yang bersambung. Nyanyian jenis ini kemudian terbagi lagi menjadi dua, yakni nyanyian liris yang sesungguhnya dan nyanyian liris yang bukan sesungguhnya; 3) nyanyian rakyat yang bersifat berkisah.

\section{Beberapa Pertimbangan Tradisi Lisan sebagai Materi ajar IPS}

Sebagaimana telah dibahas di atas, bahwa tradisi lisan memiliki banyak sekali varian, mulai dari bahasa rakyat, cerita rakyat, ungkapan tradisional, nyanyian rakyat dan lain-lain. Akan tetapi, dalam menggunakan tradisi lisan sebagai bahan pengembangan materi ajar IPS harus memperhatikan prinsip pengembangan materi ajar. 


\section{Tradisi Lisan sebagai Bahan Pengembangan Materi ajar Pendidikan IPS di SMP: Sebuah Telaah Literatur}

Sebagai blueprint rencana pembelajaran, kurikulum merupakan pedoman induk bagi setiap mata pelajaran, termasuk pendidikan IPS di SMP. Oleh sebab itu, dalam mengembangkan materi ajar, prinsif relevansi dengan kurikulum adalah hal mutlak yang harus diperhatikan. Hal ini sebagaimana dikemukakan oleh Prastowo (2013) bahwa dalam mengembangkan materi ajar, haruslah memperhatikan aspek keterkaitan dengan Kompetensi Inti dan Kompetensi Dasar. Karena itu, sebelum mengembangkan tradisi lisan sebagai materi ajar Pendidikan IPS terlebih dahulu harus di lihat apakah hal tersebut relevan/sesuai atau tidak dengan kurikulum. Hal ini dapat dilihat melalui Kompetensi Inti dan Kompetensi Dasar yang telah disusun oleh pemerintah melalui Kementerian Pendidikan dan Kebudayaan.

Adapun untuk pendidikan IPS tentu tidak semua bentuk tradisi lisan relevan dengan kurikulum di sekolah. Dengan kata lain bahwa akan ada jenis tradisi lisan yang relevan dan ada pula yang tidak relevan. Berdasarkan analisis penulis, tradisi lisan jenis ungkapan tradisional, puisi rakyat, cerita rakyat dan nyanyian rakyat adalah jenis tradisi lisan yang mempunyai banyak relevani dengan materi pembelajaran IPS di SMP. Adapun bahasa rakyat dan pentanyaan rakyat adalah jenis tradisi lisan yang kurang mempunyai relevansi dengan pendidikan IPS (Tabel 1).

Tabel 1. Contoh Relevansi Tradisi Lisan dengan Kurikulum Pendidikan IPS di SMP

\begin{tabular}{|c|c|c|c|}
\hline Kelas & Kompetensi Dasar & $\begin{array}{c}\text { Tema } \\
\text { Pembelajaran } \\
\end{array}$ & Tradisi Lisan yang Relevan \\
\hline \multirow[t]{3}{*}{ VII } & $\begin{array}{l}\text { 3.4. Memahami kronologi perubahan, } \\
\text { dan kesinambungan dalam kehidupan } \\
\text { bangsa Indonesia pada aspek politik, } \\
\text { sosial, budaya, geografis, dan } \\
\text { pendidikan sejak masa pra-aksara } \\
\text { sampai masa Hindu-Buddha dan }\end{array}$ & $\begin{array}{l}\text { - Kehidupan Masyarakat } \\
\text { pada Masa Pra Aksara }\end{array}$ & $\begin{array}{l}\text { Puisi Rakyat } \\
\text { - Cerita Rakyat } \\
\text { - Mantra } \\
\text { - Cerita Prosa Rakyat } \\
\text { - } \quad \text { Nyanyian Rakyat. }\end{array}$ \\
\hline & Islam. & $\begin{array}{l}\text { - Kehidupan Masyarakat } \\
\text { pada Masa Hindu-Budha }\end{array}$ & $\begin{array}{l}\text { - Pusi Rakyat } \\
\text { - Cerita Rakyat } \\
\text { - Mantra } \\
\text { - Cerita Prosa Rakyat } \\
\text { - } \quad \text { Nyanyian Rakyat. }\end{array}$ \\
\hline & & $\begin{array}{l}\text { - Kehidupan Masyarakat } \\
\text { pada Masa Islam }\end{array}$ & $\begin{array}{l}\text { - Ungkapan Tradisional } \\
\text { - Puisi Rakyat } \\
\text { - Cerita Prosa Rakyat } \\
\text { - Nyanyian Rakyat. }\end{array}$ \\
\hline
\end{tabular}

Sumber: Analisis data primer tahun 2019

Salah satu pertimbangan memanfaatkan tradisi lisan sebagai materi ajar IPS adalah karena posisi tradisi lisan sebagai sumber ajaran moral atau memuat nilai-nilai moral. Karena itu, setelah memastikan relevansinya dengan kurikulum, tradisi lisan yang akan dikembangkan menjadi materi ajar pendidikan IPS haruslah jenis tradisi lisan yang kaya akan muatan nilainilai. Hal ini penting mengingat bahwa tidak semua tradisi lisan yang ada kaya akan memua 
nilai. Atau dengan kata lain bahwa ada tradisi lisan mengandung nilai-nilai filosofis dan ada pula tradisi lisan yang sifatnya hanya sekedar informasi biasa. Tidak hanya itu, nilai-nilai yang terkandung dalam sebuah jenis tradisi lisan juga haruslah nilai-nilai yang relevan dengan kompetensi afektif mata pelajaran dan relevan permasalahan aktual yang dihadapi oleh suatu masyarakat.

Sebagai contoh, ungkapan tradisional pada masyarakat suku Pasemah di Bengkulu yang dikenal dengan istilah Selimbur Caye. Studi Syaputra (2018) menunjukkan bahwa tradisi lisan Selimbur Caye memuat banyak nilai-nilai sosial seperti peduli sosial, tanggung jawab, kejujuran dan keadilan, demokratik, dan lain-lain. Selain kaya akan muatan nilai, tradisi lisan tersebut sangat tepat digunakan sebagai materi ajar IPS karena relevan dengan permasalahan aktual yang sedang terjadi, yakni mulai menurunnya kesadaran sosial di kalangan anggota masyarakat. Contoh lain adalah cerita rakyat pada masyarakat Pasemah di Bengkulu sebagaimana dikaji oleh Junaidi (2017) di mana dijelaskan bahwa dari beberapa cerita rakyat yang tersebar di Kedurang, cerita rakyat Kecerdikan Sang Piatu, Sang Piatu yang Miskin, Si Sumpit, Sang Piatu Bersama Neneknya, dan Janji Sang Kerbau merupakan cerita rakyat yang kaya akan muatan nilai. Nilai-nilai yang terkandung dalam cerita rakyat tersebut ialah seperti empati sosial, religius, kreativitas, kerja keras, menepati janji dan lain-lain. Nilai-nilai tersebut merupakan nilai yang sangat dibutuhkan keberadaannya dalam kehidupan di era modern ini serta merupakan butir-butir nilai pendidikan karakter yang direkomendasikan oleh pemerintah.

Dekat dengan lingkungan peserta didik maksudnya adalah bahwa dalam memilih tradisi lisan yang akan dikembangkan menjadi materi ajar IPS hendaklah memilih tradisi lisan yang ada (berkembang) di sekitar peserta didik. Hal ini penting mengingat peserta didik tidak datang dengan pengetahuan kosong, melainkan datang dengan pengalaman dan serangkaian pengetahuan yang telah diperoleh sebelumnya di lingkungan mereka masing-masing. Hal ini sejalan dengan paradigma belajar konstruktivis, di mana belajar diposisikan sebagai sebuah proses konstruksi pengetahuan, sehingga peserta didik sebagai pembelajar mengkonstruksi sendiri pengetahuannya melalui interaksi mereka dengan objek, fenomena, pengalaman dan lingkungan mereka (Suparno, 1997). Dalam konteks tradisi lisan sebagai materi ajar IPS, maka implikasinya adalah berupa pemanfaatan tradisi lisan yang ada di sekitar lingkungan siswa. Dengan begitu, maka pembelajaran akan menjadi lebih menyatu dengan konteks sosial peserta didik (Schunk, 2012).

Sebagai contoh, cerita rakyat. Di Indonesia terdapat sangat banyak cerita rakyat, mulai dari mitos, legenda hingga dongeng. Namun, di buku-buku sekolah sering didapati cerita rakyat yang sudah akrab (Sangkuriang, Legenda Danau Toba, dll) yang berasal dari daerah tertentu. Padahal, untuk peserta didik yang jauh dari tempat cerita rakyat tersebut lahir, tentu hal tersebut merupakan sesuatu yang asing. Hal tersebut juga berdampak pada kurang dikenalnya cerita rakyat yang ada di sekitar lingkungan peserta didik. Untuk Bengkulu misalnya, alangkah baiknya jika mengangkat cerita rakyat lokal seperti: Asal Usul Nama Bengkulu, Legenda Danau Dendam Tak Sudah, Cerita Rakyat Buaya Pisang Mas, dan lain sebagainya. Untuk 


\section{Tradisi Lisan sebagai Bahan Pengembangan Materi ajar Pendidikan IPS di SMP: Sebuah Telaah Literatur}

daerah Minangkabau, dapat dimanfaatkan cerita rakyat seperti cerita Malin Kundang, asal usul nenek moyang Minangkabau, dan lain-lain.

Begitu juga untuk tradisi lisan jenis lain seperti ungkapan tradisional, puisi rakyat, dan nyanyian rakyat. Untuk ungkapan tradisional misalnya, setiap daerah di Bengkulu mempunyai banyak sekali ungkapan tradisional, dengan bahasa lokalnya masing-masing. Masyarakat Pasemah, sebagaimana dikaji oleh Syaputra (2018) mempunyai sebuah falsafah hidup yang dikenal dengan Selimbur Caye, yakni sekelompok ungkapan tradisional yang berisikan prinsifprinsif kehidupan sosial kemasyarakatan. Beberapa ungpakan tersebut misalnya seperti: Seanak Bujang Seanak Gadis, Janji Nunggu Kate Betaruh, Ndepat Mbalik Ngutang Mbayar Serame Beghagih, Seganti Setungguan, Seghepat Seghendi, Sepincang Sepejalanan, Jangan Nube Ulu Mandian, Jangan Nutuh Dahan Peninggighan, Jangan Maraska Batu ke Luagh, Jangan Ngunggung Pelidian, Jangan Menghebe Pelaluan, Jangan Nyeghuti Jalan Kayik, dll (Syaputra, 2018). Begitu juga untuk wilayah Sumatera Barat yang dapat memanfaatkan filosofi hidup orang Minangkabau, seperti Alam Takambang Jadi Guru, Adat Basandi Syarak-Syarak Basandi Kitabullah, Syarak Mangato-Adaik Mamakai, Ndak Lakang dek Paneh-Ndak Lapuk dek Ujan, dan lain-lain yang semuanya menjadi falsafah hidup bagi orang Minangkabau.

Ketiga hal tersebut di atas merupakan hal yang mutlak harus diperhatikan dalam menggunakan tradisi lisan sebagai materi ajar IPS di SMP. Di luar ketiga hal tersebut, secara umum tentu juga perlu untuk mempertimbangkan prinsip-prinsip pengembangan materi ajar yang lainnya, seperti prinsip konsistensi, prinsip kecukupan, dan lain-lain.

\section{Model Konseptual Tradisi Lisan sebagai Materi ajar IPS}

Pengembangan tradisi lisan sebagai materi ajar IPS, ada banyak model pengembangan yang dapat digunakan. Masing-masing model mempunyai tahapan atau langkah-langkah yang berbeda. Akan tetapi, secara umum tahapan tersebut dapat dibagi ke dalam tiga fase utama. Pertama, tahap analisis. Pada tahap ini yang harus dilakukan oleh guru IPS adalah melakukan analisis kebutuhan dengan mengacu kepada kurikulum yang berlaku. Pada tahap ini guru dapat melakukan pemetaan tentang kompetensi yang ingin dicapai, tujuan pembelajaran, topik pembelajaran dan lain-lain. Pada tahap ini guru juga harus melakukan identifikasi tradisi lisan yang akan dimanfaatkan sebagai materi ajar. Berbagai tradisi lisan yang ada dikumpulkan, lalu dianalisis mana yang memiliki relevansi yakni dengan kurikulum. Dalam proses seleksi ini, salah satu faktor yang harus juga dipertimbangkan ialah muatan nilai-nilai yang terkandung di dalam tradisi lisan. Tradisi lisan yang memiliki kandungan nilai-nilai yang sesuai dengan tujuan yang ingin dicapai tentu lebih diutamakan.

Kedua, desain dan pengembangan. Setelah analisis selesai dilakukan dan diperoleh tradisi lisan yang akan dijadikan materi ajar, maka selanjutnya guru menentukan bentuk materi ajar yang akan dikembangkan, apakah dalam bentuk modul, handout, buku teks atau yang lainnya. Setelah menentukan bentuk yang diinginkan, maka guru dapat mulai mengembangkan tradisi lisan sebagai materi ajar IPS. Untuk memperoleh hasil yang maksimal, guru dapat 
meminta bantuan ahli untuk dilakukan validasi. Ketiga, implementasi. Jika pengembangan materi ajar dalam bentuk yang diinginkan sudah selesai, maka tradisi lisan sebagai materi ajar pendidikan IPS dapat diimplementasikan (Gambar 1).

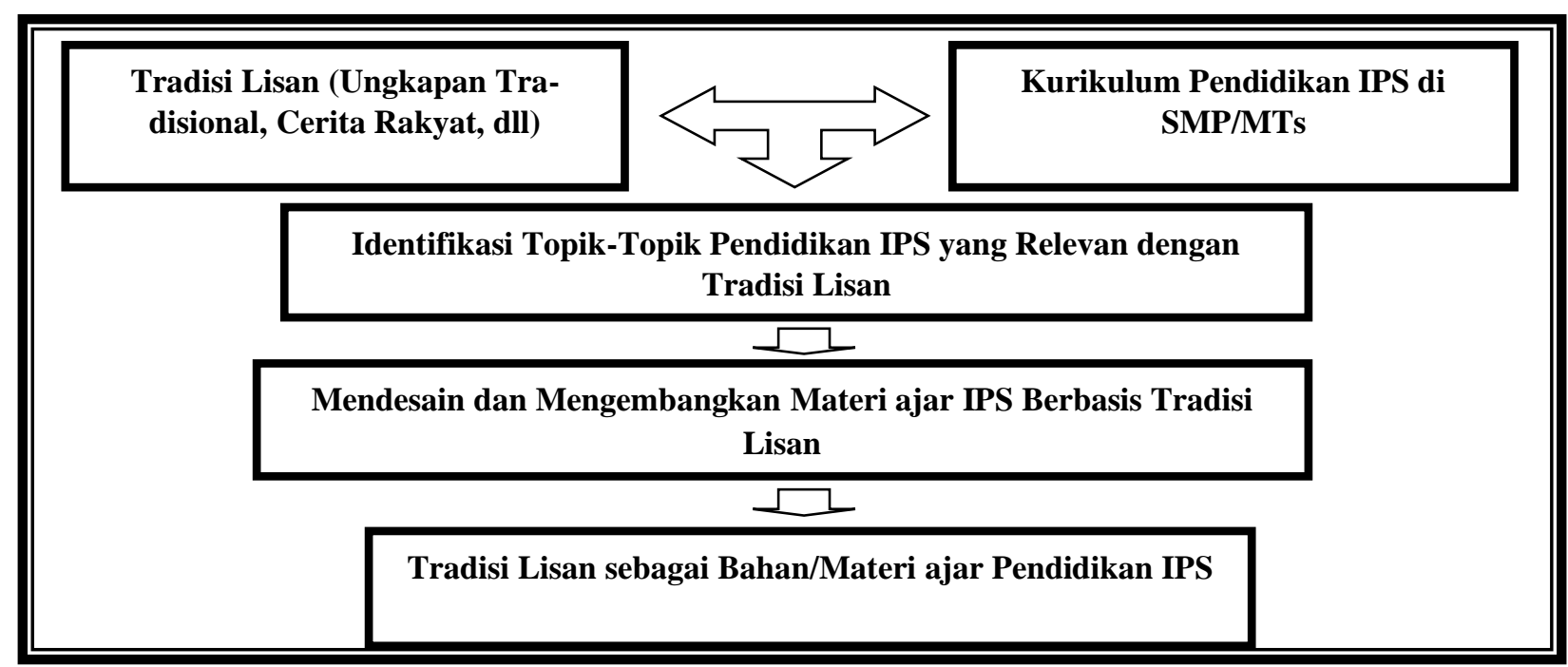

Gambar 1: Desain Skematik Tradisi Lisan sebagai Materi ajar IPS

\section{SIMPULAN}

Pembelajaran IPS di sekolah dianggap belum berhasil dalam mengembangkan peserta didik yang berkarakter baik serta memiliki kemampuan memecahkan masalah sebagai basis utama untuk menjadi warga negara yang baik. Salah satu sebab utamanya adalah karena materi pelajaran yang dianggap kurang bermakna karena akan kandungan nilai-nilai dan terpisah dari konteks sosial peserta didik. Dalam rangka mengembangkan materi pembelajaran Pendidikan IPS yang bermakna, tradisi lisan yang syarat akan nilai-nilai merupakan salah satu pilihan yang dapat digunakan.

Berbagai jenis tradisi lisan yang ada, semuanya sangat mungkin untuk dijadikan sebagai bahan pengayaan materi pembelajaran Pendidikan IPS. Akan tetapi, dari beberapa jenis tradisi lisan yang ada, terdapat empat tradisi lisan yang paling mempunyai relevansi dengan pendidikan IPS, yakni ungkapan tradisional, puisi rakyat, cerita prosa rakyat dan nyanyian rakyat. Terkait dengan pemanfaatan tradisi lisan sebagai materi ajar pendidikan IPS, ada tiga hal yang harus diperhatikan, yakni: 1) relevansinya dengan kurikulum pendidikan IPS, terutama Kompetensi Dasar; 2) kaya akan muatan nilai; dan 3) dekat dengan lingkungan peserta didik. Selain itu, pemanfaatan tradisi lisan sebagai materi ajar IPS dapat dilakukan melalui tiga tahap, yakni: 1) analisis; 2) desain dan pengembangan; dan 3) implementasi.

\section{DAFTAR PUSTAKA}

Bank, J. A. (1990). Teaching Strategies for the Social Studies: Inquiry, Valuing, and DecisionMaking. New York: Longman. 


\section{Tradisi Lisan sebagai Bahan Pengembangan Materi ajar Pendidikan IPS di SMP:}

Sebuah Telaah Literatur

Birsyada, M. I. (2016). Dasar-Dasar Pendidikan IPS: Suatu Pendekatan Teoritis dan Praktis. Yogyakarta: Ombak.

Danandjaja, J. (2007). Foklore Indonesia: Ilmu Gosip, Doengeng, dan Lain-Lain. Jakarta: Grafiti.

Duija, I. N. (2005). Tradisi Lisan, Naskah dan Sejarah: Sebuah Catatan Politik Kebudayaan. WACANA, 7 (2): 111-124.

Junaidi, F. (2017). The Value of Character Education in Andai-Andai Foklore and Its Use as Leraning Material for Literature Subject in Elementary School. International E-Journal of Advances in Education, 3 (9): 501-509.

Haryanto, J. T. (2013). Kontribusi Ungkapan Tradisional dalam Membangun Kerukunan Umat Beragama. Walisonggo, 21 (2): 365-392.

Hasan, S.H. (2012). Pendidikan Sejarah Untuk Memperkuat Pendidikan Karakter. PARAMITA: Jurnal Sejarah dan Pembelajaran Sejarah, 22 (1): 81-95.

Kemdikbud RI. (2010). Pengembangan Pendidikan Budaya dan Karakter Bangsa. Jakarta: Kemdikbud.

Kemdikbud RI. (2018). Peraturan Menteri Pendidikan dan Kebudayaan RI Nomor 35 Tahun tentang Perubahan Atas Peraturan Menteri Pendidikan dan Kebudyaan Nomor 58 tentang Kurikulum 2013. Jakarta: Kemdikbud

NCSS. (1992). In Search of a Scope and Sequence for Social Studies. Social Education, 48 (4): 249-264.

Prastowo, A. (2013). Panduan Kreatif Membuat Materi ajar Inovatif. Yogyakarta: Diva Press. Pudentia, MPSS. (2015). Metodologi Kajian Tradisi Lisan. Jakarta: Yayasan Pustaka Obor.

Ratna, N. K. (2015). Peranan Karya Sastra, Seni, dan Budaya dalam Pendidikan Karakter. Yogyakarta: Pustaka Pelajar

Sapriya. (2016). Pendidikan IPS Konsep dan Pembelajaran. Bandung: Remaja Rosdakarya.

Saripudin, D \& Komalasari, K. (2016). Culture-Based Contextual Social Studies Learning for Development Socio Cultural Values of Junior High School Students. The Social Science, 11 (23): 5726-5731.

Sariyatun. (2013). Pengembangan Model Pendidikan Nilai-Nilai Budaya di SMP Berbasis Tradisi Seni Batik Klasik Surakarta. PARAMITA: Historical Studies Journal, 23 (2): 230-241.

Satria, I. (2016). Model Pendidikan Afektif Cinta Damai. Yogyakarta: Pustaka Pelajar.

Schunk, D. H. (2012). Learning Theoris: An Educational Perspective. Terj. Eva Hamdiah \& Rahmat Fajar. Yogyakarta: Pustaka Pelajar.

Sibrani, R. (2015). Pendekatan Antropolinguistik terhadap Kajian Tradisi Lisan. RETORIKA: Jurnal Ilmu Bahasa, 1 (1): 1-17.

Suparno, P. (1997). Filsafat Konstruktivisme dalam Pendidikan. Yogyakarta: Penerbit Kanisius.

Supriatna, N. (2011). Konstruksi Pembelajaran Sejarah Berorientasi pada Permasalahan Sosial Kontemporer. Mimbar Pendidikan, 27 (1): 21-30.

Syaputra, E. (2019). Pandangan Guru Terhadap Integrasi Kearifan Lokal dalam Pembelajaran Sejarah: Studi Deskriptif-Analisis di Beberapa SMA di Bengkulu Selatan dan Kaur. Indonesian Journal of Social Science Education, 1 (1): 1-10.

Syaputra, E. Tradisi Lisan sebagai Materi ajar: Membentuk Karakter \& Melestarikan Budaya. Bengkulu Ekspres, 08/12/2019. 
Syaputra, E., Sariyatun., \& Sunardi. (2017). Socio-Cultural Values of Selimbur Caye Oral Tradition in Pasemah Ethnic Bengkulu. Advances in Social Sciences, Education and Humanities Research, 158: 228-236.

Syaputra, E., Sariyatun., \& Sunardi. (2018). The Strategy of Enhancing Students Social Awareness through History Learning Based on Selimbur Caye Oral Tradition Values. International Journal of Multicultaural and Multireligius Understanding, 5 (4): 22-29. Winataputra. (2007). Paradigma Pendidikan IPS Indonesia. Jakarta: Universitas Terbua.

Zed, M. (2008). Metode Kepustakaan. Jakarta: Obor. 